\title{
THIETHYLPERAZINE: A CLINICAL INVESTIGATION OF A NEW ANTI-EMETIC DRUG
}

\author{
Cyrul Taylor, m.D., and Vergil K. Stoelting, m.d. *
}

MANY DRUGS have been introduced during the past decade to prevent or to control postoperative emesis. It is not surprising, however, in view of the multiplicity of contributing factors, that the complete prevention of this complication is not yet possible. In most instances postoperative emesis is self-limiting, of short duration, and threatens little physical or emotional danger to the patient. When significant difficulties from vomiting or retching can be anticipated, or have developed, then the employment of anti-emetic drugs is rational and useful therapy. There can be little argument against the repeated warnings that the routine use of these drugs is undesirable. ${ }^{1}$ Some of these agents produce sideeffects -which may be more harmful than the emesis which they may, or may not, have suppressed. Research endeavours in this field must continue in an effort to discover a drug which has maximal efficacy and minimal complications.

This report describes the clinical investigation of a new phenothiazine compound, thiethylperazine malate (Torecan ${ }^{\circledR}$ ), which has been reported to have minimal tranquillizing properties, and yet to have highly effective anti-emetic activity. ${ }^{2}$ The study was designed to determine its value in preventing postoperative emesis, and, with equal vigour, any side-effects that might appear during its use.

Thiethylperazine malate has the chemical designation 2-ethylmercapto-10-[3'( $1^{\prime \prime}$-methyl-piperazinyl-4" $4^{\prime \prime}$-propyl-1']-phenothiazine dimalate (Fig. 1). Its chemical structure is related to that of prochlorperazine, from which it differs by having a thioethyl radical in position 2 of the phenothiazine nucleus, instead of a chlorine. The drug has been demonstrated, with laboratory animals, to have a

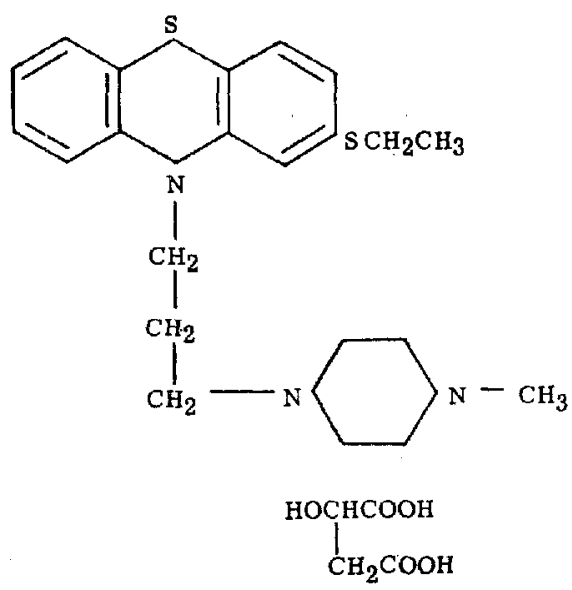

Figure 1. Thiethylperazine malate.

Department of Anesthesiology, Indiana University School of Medicine, Indianapolis,
Indiana. 
low toxicity in relation to its effective dose. Pharmacologic studies have shown that it provides effective protection against vomiting induced in dogs by apomorphine and copper sulphate. ${ }^{3}$

\section{METHOD OF STUDY}

A double-blind technique was employed. Identical ampoules were obtained, which contained thiethylperazine, $5.0 \mathrm{mg}$. per $\mathrm{ml}$., or a placebo. The individual ampoules were numbered in a random fashion, and mixed in a large box. The anaesthesiologist "drew" one ampoule from the box for each of his patients. All patients over 16 years of age undergoing elective surgery, except open-heart surgery or intracranial neurosurgery, during the period of study were included.

Each patient received the drug or placebo, by intramuscular injection, when the administration of the anaesthetic was terminated. The patients were carefully observed in the recovery room, and the relevant information was recorded on prepared forms, every 15 minutes for 2 hours. Thiethylperazine was investigated in this manner at $5.0 \mathrm{mg}$. and $10.0 \mathrm{mg}$. dose levels. Table I shows the distribution

TABLE I

Distribution with Regard to Sex, Anaesthetic Agent, and Surgical Procedtres

\begin{tabular}{|c|c|c|c|}
\hline & Placebo & $\begin{array}{c}\text { Thiethy lpera } \angle 1 \text { ne, } \\
5 \mathrm{mg}\end{array}$ & $\begin{array}{c}\text { Thiethy lperazine, } \\
10 \mathrm{mg} .\end{array}$ \\
\hline $\begin{array}{l}\text { Sex } \\
\quad \text { Males } \\
\text { Females }\end{array}$ & $\begin{array}{r}95 \\
169\end{array}$ & $\begin{array}{r}89 \\
100\end{array}$ & $\begin{array}{r}84 \\
126\end{array}$ \\
\hline $\begin{array}{l}\text { Anaesthetic Agent } \\
\text { Cyclopropane } \\
\text { Ether } \\
\text { Fluothane } \\
\text { Vitrous oxide - barbiturate } \\
\text { Regional }\end{array}$ & $\begin{array}{r}101 \\
9 \\
127 \\
24 \\
3\end{array}$ & $\begin{array}{l}85 \\
11 \\
\frac{1}{17} \\
2\end{array}$ & $\begin{array}{r}82 \\
16 \\
95 \\
15 \\
2\end{array}$ \\
\hline $\begin{array}{l}\text { Surgical Procedure } \\
\text { Cardiovascular } \\
\text { Pulmontary } \\
\text { Upper abdominal } \\
\text { Lower abdominal } \\
\text { Gynaecologic perineal } \\
\text { Orthopaedic } \\
\text { E.N.T. } \\
\text { Plastic } \\
\text { Oral } \\
\text { Genito-urinary perineal } \\
\text { Neurosurgery } \\
\text { (except intracranial) }\end{array}$ & $\begin{array}{l}14 \\
16 \\
22 \\
59 \\
61 \\
15 \\
13 \\
16 \\
10 \\
16\end{array}$ & $\begin{array}{r}8 \\
12 \\
19 \\
39 \\
49 \\
11 \\
8 \\
11 \\
12 \\
12\end{array}$ & $\begin{array}{r}8 \\
10 \\
23 \\
47 \\
58 \\
10 \\
12 \\
13 \\
15 \\
10\end{array}$ \\
\hline Toral & 264 & 189 & 210 \\
\hline
\end{tabular}

in the three groups with regard to sex, anaesthetic agent, and surgical procedure. Wherever statistical evaluation was necessary the chi-squared test was employed, and values of $p<0.05$ were considered significant.

RESULTS

The Effectiveness of Thiethylperazine in the Prevention of Postoperative Emesis

It was found that $5.0 \mathrm{mg}$. and $10.0 \mathrm{mg}$. doses of thiethylperazine produced a 
significant decrease in the incidence of emetic symptoms, when a comparison was made with the placebo group. This is expressed in Table II as percentage reduction in symptoms.

TABLE II

Therapeutic Effectiveness of Thiethylperazine in |The Prophylaxis of Postorerative Emesis

\begin{tabular}{lccc}
\hline & Placebo & $\begin{array}{c}\text { Thiethylperazine, } \\
5 \mathrm{mg} .\end{array}$ & $\begin{array}{c}\text { Thiethylperazine, } \\
10 \mathrm{mg} .\end{array}$ \\
\hline $\begin{array}{l}\text { Total no. of patients } \\
\text { No. of patients with retching } \\
\text { or vomiting }\end{array}$ & 264 & 189 & 210 \\
$\begin{array}{c}\text { \%of patients with retching } \\
\text { or vomiting }\end{array}$ & 61 & 21 & 17 \\
$\begin{array}{c}\text { \% decrease in retching or } \\
\text { romiting }\end{array}$ & 231 & 111 & 81 \\
$\begin{array}{l}\text { No. of patients with nausea, } \\
\text { retching, or vomiting }\end{array}$ & - & 519 & 649 \\
$\begin{array}{c}\text { \%of patients with nausea, } \\
\text { retching, or vomiting }\end{array}$ & 273 & 27 & 19 \\
$\begin{array}{c}\text { ic decrease in nausea, retching, } \\
\text { or vomiting }\end{array}$ & - & 143 & 90 \\
\hline
\end{tabular}

The division of symptoms into retching and vomiting, and nausea, retching, and vomiting, was made to allow these results to be compared with those described by other investigators using other anti-emetics. Thiethylperazine compared very favourably with these other drugs in the prevention of postoperative emesis., ${ }^{4-11}$

\section{Side-Effects of Thiethylperazine}

1. Postanaesthetic somnolence. The degree of arousal from general anaesthesia was noted at 15-minute intervals. The following classification was used:

0 -wide-awake,

1-slightly drowsy, but able to engage in a rational conversation,

2-moderately drowsy, but still able to answer questions,

3-very drowsy, but still able to respond to commands,

4-very drowsy, with response only to painful stimuli,

5-unresponsive.

It was believed that this multiple classification allowed a simple unbiased distinction between the different levels of arousal.

The sedative effect of any drug employed in the manner described, whether as the result of potentiation or addition, would be particularly evident with patients recovering from general anaesthesia. In the clinical practice of anaesthesiology, it is usually accepted that patients should be sufficiently awake to engage in a rational conversation as soon as possible following the termination of anaesthesia. The rate of arousal is expressed for each group, at 15-minute intervals, as the percentage of the group at level 1 . The difference between the three groups of patients is demonstrated in Figure 2. The arousal of patients 


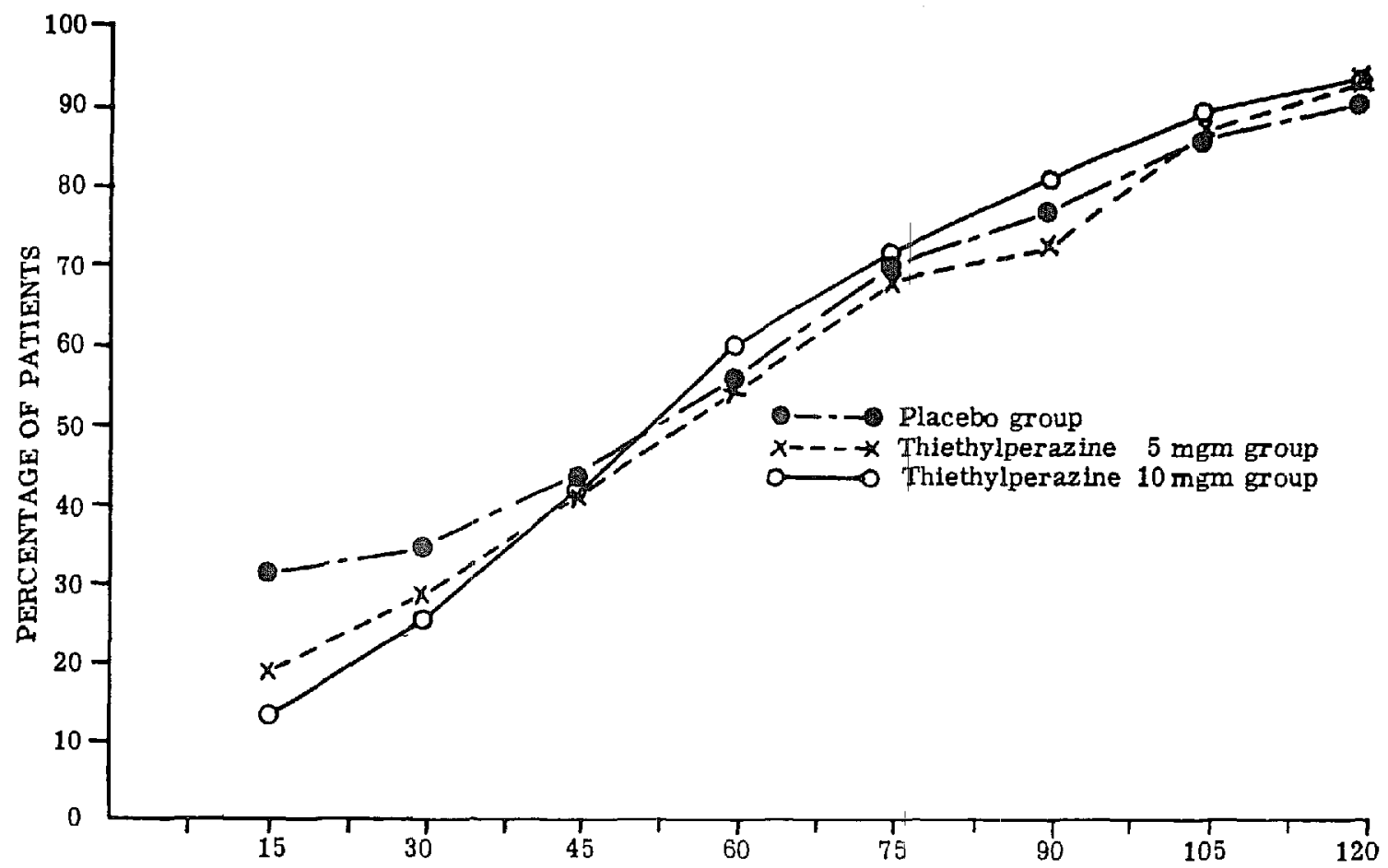

TIME FOLLOWING INJECTION OF STUDY DRUG (TERMINATION OF ANESTHESIA) IN MINUTES

FIGURE 2. The rate of arousal from general anaesthesia. The relationship between the percentage of patients in each group sufficiently awake to engage in a rational conversation (level 1), and the time following the termination of general anaesthesia.

who had received thiethylperazine, $5.0 \mathrm{mg}$., was significantly different from the placebo group at the 15-minute period, but not at later periods. The patients who had received thiethylperazine, $10 \mathrm{mg}$., had a significantly smaller percentage of its members in level 1 at the 15- and the 30-minute period than the placebo group. This would appear to indicate that thiethylperazine had a mild sedative effect, since it only slightly prolonged postanaesthetic somnolence.

2. Hypotension. Table III represents the percentages of patients in each of the three groups whose systolic blood pressure decreased from the preanaesthetic level during the immediate 2-hour postanaesthetic period. The systolic blood pressure returned to this "basal" level with all of these patients either spontaneously or following the administration of vasopressor drugs, blood, or plasma

TABLE III

The Miximal Decrease in Systolic Blood Pressure from the Preaxaesthetic LEVIEL DURING THE IMMEDIATF 2-HdLR POSTOPERATIVE PERIOD

\begin{tabular}{|c|c|c|c|}
\hline $\begin{array}{c}\text { Decrease in systolic } \\
\text { blood pressure, } \\
\text { mm. Hg }\end{array}$ & $\begin{array}{c}{ }^{c}{ }_{c} \text { of total patients } \\
\text { who received } \\
\text { placebo }\end{array}$ & $\begin{array}{c}c-16 \text { of total patients } \\
\text { who received } \\
\text { thiethylperazine, } \\
5 \mathrm{mg} \text {. }\end{array}$ & $\begin{array}{c}C_{C} \text { of total patients } \\
\text { who received } \\
\text { thiethylperazine, } \\
10 \mathrm{mg} .\end{array}$ \\
\hline $\begin{array}{c}20-30 \\
30-40 \\
40-50 \\
50\end{array}$ & $\begin{array}{rl}15 & 9 \\
4 & 5 \\
3 & 8 \\
1 & 9\end{array}$ & $\begin{array}{rl}1 & 1 \\
1 & 6 \\
1 & 7 \\
3 & 7 \\
2 & 1\end{array}$ & $\begin{array}{rl}15 & 7 \\
7 & 1 \\
10 & 0 \\
2 & 4\end{array}$ \\
\hline Total no. of patients & 264 & 189 & 210 \\
\hline
\end{tabular}


expanders. A decrease in the systolic blood pressure exceeding $30 \mathrm{~mm} . \mathrm{Hg}$ occurred more frequently in the group of patients who had received $10.0 \mathrm{mg}$. of thiethylperazine. This difference was statistically significant.

3. Changes in pulse rate. Tables IV and V represent the percentages of patients

TABLE IV

The Maximal Increase in Pulse Rate from the Preanaesthetic Level dering the Immediate 2-Hour Postoperative Period

\begin{tabular}{|c|c|c|c|}
\hline $\begin{array}{l}\text { Increase in pulse } \\
\text { rate above } \\
\text { basal level, } \\
\text { per min. }\end{array}$ & $\begin{array}{c}\% \text { of total patients } \\
\text { who received } \\
\text { placebo }\end{array}$ & $\begin{array}{c}\text { of total patients } \\
\text { who received } \\
\text { thiethylperazine, } \\
5 \mathrm{mg} \text {. }\end{array}$ & $\begin{array}{c}\text { \% of totalpatients } \\
\text { who received } \\
\text { thiethylperazine, } \\
10 \mathrm{mg} \text {. }\end{array}$ \\
\hline $\begin{array}{c}20-30 \\
30-10 \\
40-50 \\
\text { Over } 50\end{array}$ & $\begin{array}{rl}18 & 0 \\
3 & 8 \\
0 & 8 \\
0 & \end{array}$ & $\begin{array}{rl}11 & 6 \\
1 & 8 \\
0 & 5 \\
0 & \end{array}$ & $\begin{array}{rr}10 & 0 \\
7 & 2 \\
1 & 4 \\
0 & \end{array}$ \\
\hline Total no. of patients & 264 & 189 & 210 \\
\hline
\end{tabular}

TABLE V

The Maximal Dickiasi in Pllse Rate from the Preayarsthetic Level dl kisg ihi: IMmediatr 2-Hock Postoperatine Period

\begin{tabular}{|c|c|c|c|}
\hline $\begin{array}{l}\text { Decrease in pulse } \\
\text { rate below } \\
\text { basal level, } \\
\text { per min }\end{array}$ & $\begin{array}{c}\text { 'of total patients } \\
\text { who rec eived } \\
\text { placebo }\end{array}$ & $\begin{array}{c}\text { 'c of total patients } \\
\text { who received } \\
\text { thiethy lperazine, } \\
5 \mathrm{mg} \text {. }\end{array}$ & $\begin{array}{c}\text { 'c of total patients } \\
\text { who received } \\
\text { thiethylperazine, } \\
10 \mathrm{mg} .\end{array}$ \\
\hline $\begin{array}{l}20-30 \\
30-40 \\
40-50\end{array}$ & $\begin{array}{l}45 \\
0 \\
0 \\
0\end{array}$ & $\begin{array}{ll}3 & 2 \\
3 & 7 \\
0\end{array}$ & $\begin{array}{ll}6 & 2 \\
0 & \\
0 & 5\end{array}$ \\
\hline Total ho of patients & 264 & 189 & 210 \\
\hline
\end{tabular}

in each group whose pulse rate increased or decreased, respectively, from the preanaesthetic "basal" level during the immediate 2-hour postoperative period. There was no significant difference between the groups of patients.

4. Emergence restlessness. The incidence of restlessness during the emergence from general anaesthesia was observed in these patients because: $(a)$ the sedative effect of the drug might allow a quieter arousal from general anaesthesia, (b) some phenothiazine drugs produce restlessness, $(c)$ restlessness during the emergence from general anaesthesia may be a manifestation of the release of extrapyramidal centres during the period when the cerebral cortex is still depressed by the anaesthetic. If thiethylperazine caused extrapyramidal centre reactions, as has been described with other anti-emetic drugs, ${ }^{12}$ then postanaesthetic restlessness might be more evident in the groups of patients who had received the drug.

Statistical comparison of the data from the three groups revealed no significant differences (Table VI).

5. Emergence rigidity. The tonic muscular rigidity which is occasionally seen during the emergence from general anaesthesia may also be an extrapyramidal centre release phenomenon. It was decided to examine the incidence of this 
TABLE VI

The Percentage of the Total Patients in Each Grodp Who Manifested Motor Restlessness during Emergence from General Anaesthesia

\begin{tabular}{|c|c|c|c|}
\hline $\begin{array}{l}\text { Degree of motor } \\
\text { restlessness }\end{array}$ & $\begin{array}{c}10 \text { of total patients } \\
\text { who received } \\
\text { placebo }\end{array}$ & $\begin{array}{c}C_{\%} \text { of total patients } \\
\text { who received } \\
\text { thiethylperazine, } \\
5 \mathrm{mg} .\end{array}$ & $\begin{array}{c}\% \text { of total patients } \\
\text { who received } \\
\text { thiethylperazine, } \\
10 \mathrm{mg} .\end{array}$ \\
\hline $\begin{array}{l}\text { Mild } \\
\text { Moderate } \\
\text { Severe }\end{array}$ & $\begin{array}{rl}12 & 9 \\
4 & 5 \\
3 & 4\end{array}$ & $\begin{array}{rl}21 & 7 \\
2 & 6 \\
9^{2} & 1\end{array}$ & $\begin{array}{rl}13 & 3 \\
4 & 3 \\
3 & 3\end{array}$ \\
\hline Total no. of patients & 261 & $18 \vec{t}$ & 208 \\
\hline
\end{tabular}

TABLE VII

The Plrcentage of the Total Patiexts ys Each Grol p I ho Developed Muscclar Rigiditi diring Emergince from Ana esthesia

\begin{tabular}{|c|c|c|c|}
\hline $\begin{array}{c}\text { Degree of } \\
\text { muscular rigidity }\end{array}$ & $\begin{array}{c}i \text { of total patients } \\
\text { who received } \\
\text { placebo }\end{array}$ & $\begin{array}{c}\text { cof totinl patients } \\
\text { who received } \\
\text { thiethy lperazine, } \\
5 \text { mg. }\end{array}$ & $\begin{array}{c}Y_{c} \text { of total patients } \\
\text { who received } \\
\text { thiethylperazine, } \\
10 \mathrm{mg} .\end{array}$ \\
\hline $\begin{array}{l}\text { Mild } \\
\text { Moderate } \\
\text { Severe }\end{array}$ & $\begin{array}{ll}1 & 5 \\
1 & 9 \\
0 & \end{array}$ & $\begin{array}{ll}2 & 1 \\
3 & 7 \\
0 & \end{array}$ & $\begin{array}{ll}1 & 4 \\
3 & 3 \\
0 & \end{array}$ \\
\hline Total no. of patients & 261 & 187 & 208 \\
\hline
\end{tabular}

rigidity in the three groups of patients to determine whether an increase could be interpreted as evidence of extrapyramidal centre stimulation. There were no significant differences between the groups of patients (Table VII).

\section{Discussion}

Emesis is the most common postoperative complication, but, if the patient is awake, it is one of the least important. Many patients, however, gauge the professional skill of their anaesthesiologist by its presence or absence. Even some surgeons are prepared to lay the entire blame for emesis on the anaesthetic agent or the anaesthesiologist. It must be admitted that these may play an important role in its development, but the surgeon and even the patient may contribute the primary aetiologic factor causing the emesis. ${ }^{13,14}$ The well-advertised introduction of anti-emetic drugs has led some anaesthesiologists and surgeons to accept them as the complete answer to a vexing problem. In fact, it is difficult to conceive of any drug that will be capable of suppressing the effects of a multiplicity of contributing factors. A consideration of these factors, however, may allow some of them to be controlled for a particular patient, and should be part of the over-all plan in the attempt to prevent postoperative emesis. ${ }^{13}$ If emesis does create significant problems, then an anti-emetic drug is a necessary and useful aid.

The side-effects of the anti-emetics have been a significant disadvantage. At present, the drugs that have the least complications offer the least protection. A review of the medical literature suggests that the phenothiazine compounds are 
the most effective.4-12 However, they may cause excessive drowsiness, hypotension, tachycardia, bradycardia, and extrapyramidal reactions. The possible danger of these side-effects must always be considered for each patient if the employment of an anti-emetic drug is contemplated.

All of the patients included in this study were visited during the morning following surgery. An interesting feature revealed by these visits was that the patient's own evidence as to whether he had vomited was entirely unreliable. Many did not recall that they had vomited during their stay in, the recovery room.

Thiethylperazine is a forward step in the drive to find an efficient anti-emetic with minimal side-effects. It was as efficient as the other phenothiazine compounds in preventing the development of postoperative emesis ${ }^{4-11}$ Postanaesthetic somnolence was only slightly prolonged. The group of patients who had received $10.0 \mathrm{mg}$. of thiethylperazine demonstrated a significantly higher incidence of hypotension than the other two groups. When the study was designed, it was hoped that observation of the ęmergence phenomena, restlessness, and muscular rigidity might serve to indicate whether the drug exhibited the tendency to provoke extrapyramidal reactions. If these phenomena are due to the release of the extrapyramidal centres, whilst the cerebral cortex is depressed, then any drug which produces extrapyramidal stimulation might cause them to appear more frequently. Analysis of the data, however, did not yield any significant differences between the groups. It appeared, therefore, that either the drug was free of this tendency, or that this line of investigation was of no value in this respect. It is intended to pursue these thoughts further, during other anti-emetic drug evaluation studies at this institution.

\section{SUMMARY}

A new phenothiazine compound, thiethylperazine malate, was investigated with regard to its effectiveness in preventing postoperative emesis and to its sideeffects. A double-blind technique was employed. Thiethylperazine or a placebo was injected intramuscularly at the termination of anaesthesia, and the patient was observed in the recovery room for two hours. There was a significant reduction in the incidence of postoperative emesis in patients who had received $5.0 \mathrm{mg}$. or $10.0 \mathrm{mg}$. of thiethylperazine. There was a slight prolongation of postanaesthetic somnolence by the drug. Hypotension, greater than $30 \mathrm{~mm}$. Hg, was more frequent in the group of patients who had received $10.0 \mathrm{mg}$. of thiethylperazine. No other side-effects were detected. Thiethylperazine appeared to be a very useful anti-emetic, and is a forward step in the drive to find one with maximal efficiency and minimal side-effects.

\section{ACKNOWLEDGMENTS}

The authors would like to express their gratitude to Mrs. Evelyn S. Craig, R.N., and her staff for their assistance during this investigation. 


\section{RÉSUMÉ}

Il existe encore un besoin de médicaments antiémétiques qui possèderaient une efficacité maxima et des effets secondaires minima. Au cours de cette enquête, nous avons étudié la thiéthylpérazine, un composé de la phénothiazine, pour établir sa capacité de prévenir les vomissements post-opératoires et déceler les effets secondaires qu'elle pourrait produire.

Nous avons utilisé une technique à double inconnu. Cette enquête a été faite sur 663 malades qui avaient subi une opération élective. Chacun de ces malades a reçu, en injection intra-musculaire, à la fin de lanesthésie, soit de la thiéthylpérazine soit du placebo. Ensuite ils ont été garde's sous observation durant dęux heures dans la salle de réveil et les remarques appropriées ont été compilées sur des feuilles préparées à cet effet.

Les données statistiques ont été établies en employant la méthode khi-carrée. Nous avons établi que des doses de 5 et de $10 \mathrm{mg}$. cle thiéthylpérazine diminuaient de façon notable la fréquence des vomissements post-opératoires. Après l'anesthésie générale, le réveil a été légèrement plus tardif chezlles malades qui avaient reçu de la thiéthylpérazine. Les hypotensions, dépassant $30 \mathrm{~mm}$. de mercure, ont été en peu plus nombreuses dans le sroupe de malades qui avaient reçu $10 \mathrm{mg}$. de thiéthylpérazine. Selon toute apparence, la thiéthylpérazine ne produit pas d'autres effets secondaires.

La thiéthylpérazine semble être un pas de plus vers la découverte d'un antiémétique efficace ne produisant qu'un minimum d'effets secondaires.

\section{REFERENCES}

1. Adrtani, J.; Summens, F. W.; \& Antony, S. O. Is the Prophylactic Use of Antiemetics in Surgical Patients Justified? J.A.M.A. 175: 666 (196il).

2. Browne, D. C. \& Sparks, R. Vomiting Mechanisms: A Clinical Study of Thiethylperazine. So. Med. J. 54: 953-961 (1961).

3. Cox, J. \& Collins, J. H. Nausea and Vomiting: Control by Thiethylperazine. Curr. Therap. Research 4: 178-181 (1962).

4. Ouellette, R. D. Control of Postoperative Nause.l and Vomiting with Trimethobenzamide. Anesth. \& Analg. 41: 148-153 (1962).

5. Wolfson, B.; Torres-Kay, M.; \& Foldes, F. F. Investigation of Usefulness of Trimethobenzamide for the Prevention of Postoperative Nausea and Vomiting.: Anesth. \& Analg. 41: 172-177 (1962).

6. Bellville, J. W.; Bross, I. D. J.; \& Howland, IF. S. The Antimetic Efficacy of Cyclizine (Marezine) and Tritupromazine (Vesprin). Anesthesiology 20: 761-766 (1959).

7. Tullaman, W. W., JR.; Wise, G. F.; \& Crawford, (). B. Evaluation of Marezine and Bonamine in Lowering the Incidence of Postoper.llive Nausea and Vomiting. Anesthesiology 17: 112-115 (1956).

8. KNapp, M. R. \& Beecher, H. R. Postanesthetic Nauwa, Vomitirg and Retching-Evaluation of Antiemetic Drugs, Dimenhydrinate (Dranuanine) Chlorpromazine and Pentobarbital Sodium. J.A.M.A. 160: 376-385 (1956).

9. Didier, E. P.; Barila, T. Gi; Slocum, H. C.; Lindgri... V. V.: \& McCawley, E. L. The Evaluation of Antiemetic Drugs in the Control of r'ustoperative Nausea and Vomiting. Surg. Forum v: 707-712 (1954).

10. Moore, D. C.; Brmenbaugh, L. D.; Piccion, V. F.; londis, P. A.; \& Lindstrom, C. A. Control of Postoperative Vomiting with Marezine: A Double Blind Study. Anesthesiology 17: 690-695 (1956).

11. Moore, D. C.; Brmenbaugh, L. D.; VanAckerex, I. G.; \& Cole, F. V. Control of Postoperative Vomiting with Perphenazine (Trilafon): A Double Blind Study. Anesthesiology 19: 72 (1958). 
12. Bellville, J. W. Postanesthetic Nausea and Vomiting. Anesthesiology 22: 773-780 (1961).

13. Taylor, C.; Gardier, R. W.; \& Stoelting, V. K. Postoperative Emesis-Etiology and Control. Scientific Exhibit, N.Y. St. Soc. of Anesthesiologists, Fifteenth Postgraduate Assembly, New York (December, 1961).

14. Belleville, J. W.; Bross, I. D. J.; \& Howland, W. S. Postoperative Nausea and Vomiting IV: Factors Related to Postoperative Nausea and Vomiting. Anesthesiology 21: 186-193 (1960). 